\title{
Interactive comment on "Estimating contributions from biomass burning and fossil fuel combustion by means of radiocarbon analysis of carbonaceous aerosols: application to the Valley of Chamonix" by Lise Bonvalot et al.
}

\section{S. Preunkert \\ preunkert@Igge.obs.ujf-grenoble.fr \\ Received and published: 8 August 2016}

This study presents PM10 aerosol data obtained in summer and winter in a valley of the French Alps. Among others, a source apportionment study has been made with the aim to distinguish sources as fossil fuel, biomass burning and biogenic emissions on the base of $14 \mathrm{C}$ measurements and levoglucosan. This revealed that summer samples exhibit an important relative contribution of non-fossil sources and a dominant contribution of biomass burning in winter. Interestingly, this very valuable data set and its important conclusions are similar to what was obtained in two source apportionment 
studies (Gelencsér et al., 2007; May et al., 2009) made on the basis of a two year round data set sampled on a weekly basis at five rural/remote sites in Europe. These detailed literature data set reflects atmospheric conditions of 2002/2003 on a European west east transect at altitudes from 40 to $3100 \mathrm{~m}$ asl. Given the fact that the source apportionment calculations were very similar than ins this study here, i.e. including also $14 \mathrm{C}$ and levoglucosan measurements to distinguish fossil, biomass burning and biogenic emissions, it might be worth that the authors have a look on this dataset and benefit by comparing their new results with these existing literature data.

\section{References:}

Gelencsér, A., B. May, D. Simpson, A. Sánchez-Ochoa, A. Kasper-Giebl, H. Puxbaum, A. Caseiro, C. Pio, and M. Legrand (2007), Source apportionment of PM2.5 organic aerosol over Europe: Primary/secondary, natural/anthropogenic, and fossil/biogenic origin, J. Geophys. Res., 112, D23S04, doi:10.1029/2006JD008094.

MAY, B., WAGENBACH, D., HAMMER, S., SteIER, P., PUXBAUM, H. and PIO, C. (2009), The anthropogenic influence on carbonaceous aerosol in the European background. Tellus B, 61: 464-472. doi:10.1111/j.1600-0889.2008.00379.x

Interactive comment on Atmos. Chem. Phys. Discuss., doi:10.5194/acp-2016-351, 2016. 